\title{
Seroprevalence of Toxoplasma gondii antibodies using Sabin- Feldman dye test among equines in Isparta province, Turkey
}

\section{Original Article}

\author{
Mehmet Aciöz ${ }^{1}$, Faruk Bozkaya ${ }^{2}$, Cahit Babür ${ }^{3}$ \\ Province Directorate of Agriculture and Forestry, Muğla ${ }^{1}$, Harran University, Faculty \\ of Veterinary Medicine, Department of Genetics, Şanlıurfa ${ }^{2}$, Turkish Public Health \\ Institution, Sihhiye, Ankara ${ }^{3}$, Turkey
}

\begin{abstract}
Background: Toxoplasmosis is a protozoan disease widely spread among different animal species with an incidence of up to $90 \%$. The presence of this agent among equine species has been reported to be about 46.3\%. T. gondii infection in equids could favor the spreading of the infection as equine carcasses are used for animal diets in zoos, as well as dead equine carcasses left outside villages are eaten by stray dogs and cats. This study was conducted to determine the seroprevalence of T. gondii among equine species (horses, donkeys, and mules) raised in Isparta province of Turkey by using Sabin Feldman dye test (SFDT) which is a reference test widely used for detecting T. gondii antibodies in different animal species.

Objective: The aim of this study was to investigate the seroprevalence of T. gondii among equids in Isparta province, Turkey.

Material and Methods: Blood samples were collected from 192 animals including horses ( $\mathrm{n}=72)$, donkeys $(n=88)$ and mules $(n=32)$ from January to December of 2016. Separated sera were tested for anti-T. gondii antibodies using SFDT.

Results: Out of 192 samples, 44 (22.9\%) reacted positive. Sero-positivity was 27.8\%, 18.2\% and 25.0\% in horses, donkeys, and mules, respectively with no statistical difference. According to age of animals, the seroprevalence was $14.3 \%, 32.8 \%$, and $20.8 \%$ in age groups $0-5,6-10$ and over 11 years, respectively with a statistically significant difference. Sero-positivity in male animals was $19.44 \%$ and in females $25.0 \%$, with no statistical difference.
\end{abstract}

Conclusion: The prevalence of exposure to T. gondii was determined as $22.9 \%$ in equids in Isparta province.

Keywords: donkeys, horses, Isparta, mules, serology, toxoplasmosis, Turkey.

Received: 25 March, 2020, Accepted: 25 May, 2021.

Corresponding Author: Mehmet Aciöz, Tel.: +90 5079594373, E-mail: mehmetacioz@hotmail.com

Print ISSN: 1687-7942, Online ISSN: 2090-2646, Vol. 14, No. 2, August, 2021.

\section{INTRODUCTION}

Toxoplasmosis is a parasitical disease of zoonotical chacracter which is wide spread in the World as well as in Turkey ${ }^{[1]}$. End host of $T$. gondii are members of felidae family while it causes disease in intermediate hosts such as humans, birds and other mammalian species. It grows in intermediate hosts in two phases. In the first phase it rapidly proliferates trough endodyogeny and develops tachysoites. In the second phase, it divides slowly as bradyzoites in tissue cysts $^{[2]}$. The cysts settle in tissues such as skeletal or cardiac muscles, brain, lungs, liver and kidneys and cause latent toxoplasmosis that may become reactivated ${ }^{[2]}$. The infection occurs widely by ingestion of contaminated foods and raw or soft-boiled meats. Infection through congenital transmission from mother to offspring and organ transplantation has also been observed ${ }^{[1]}$. Sabin Feldman dye test is a quite sensitive test for detection of IgG antibodies against $T$. gondii. It has been reported that a titer of $1: 16$ or 4 IU should be accepted as positive for toxoplasmosis ${ }^{[3]}$.
Equids (donkeys, mules, horses) are especially important domestic animals in Turkey used for transportation and racing. Industry of racehorses in Turkey is estimated to be worth 1 billion dollars yearly ${ }^{[3]}$. The total number of equids in Isparta province was reported as 2880 including 598 horses, 230 mules, 2052 donkeys ${ }^{[4]}$. T. gondii infections in horses is generally of subclinical course. Several case studies reported elevated titers in horses with chorioretinitis and in one horse with optic nerve atrophy ${ }^{[5]}$. However several studies showed no association of antibody titers with ocular lesions ${ }^{[6,7]}$ or with Equine Recurrent Uveitis (ERU) in horses ${ }^{[8]}$. Toxoplasmosis in equids poses no direct risk for human health because equine meat is not consumed in Turkey. However T. gondii infection in equids could favor the spreading of the infection as equine carcasses are used for animal diets in zoos, as well as dead equine carcasses left outside villages are eaten by stray dogs and cats ${ }^{[9]}$. Therefore, investigating the prevalence of $T$. gondii infection in equine species could contribute to monitoring this infection in the population. 
Sabin Feldman dye test is a reference test which is performed in reference laboratories where tachyzoites obtained from cell cultures or experimental mice are used $^{[3]}$. The aim of this study was to determine the seroprevalence of $T$. gondii infection in equids from Isparta province, Turkey.

\section{MATERIAL AND METHODS}

This descriptive analytical study was conducted at the Parasitology Laboratory of Turkish Public Health Institution. where SFDT is performed as a routine for diagnosis of toxoplasmosis, during the period from January 2016 to December 2016.

Study area and animals: Isparta province is located in the western and inner parts of the Mediterranean Region of Turkey and is also named as Region of Lakes (38 $17^{\circ} 58.1028^{\prime \prime} \mathrm{N}-31^{\circ} 10^{\prime} 32.8944^{\prime \prime} \mathrm{E}$ ). This location lies in the transition zone between Mediterranean climate and the continental climate of Central Anatolia. Blood samples were collected from 192 equids (72 horses, 88 donkeys and 32 mules) into sterile tubes from the punctured jugular vein.

Serology: Sera were obtained by centrifuging the blood samples at $25^{\circ} \mathrm{C}$ at $4000 \mathrm{x} \mathrm{g}$ for $10 \mathrm{~min}$, and stored at $-20^{\circ} \mathrm{C}$ until analysis using SFDT ${ }^{[10]}$. Dilutions of $1 / 16$ and above were evaluated as positive.
Statistical analysis: Statistical analysis was performed with SPSS version 20. Differences with respect to seroprevalence among the equine species, age groups or sexes were assessed using Chi-square test. Statistical significance was considered when $P$ values were less than 0.05

Ethical Statement: This study was carried out according to the article 10 of Directives on Duties, Working Procedures and Principles of the Provincial Organization of the Ministry of Food, Agriculture and Livestock.

\section{RESULTS}

Out of all 192 samples, 44 (22.9\%) reacted positive including 20 (27.8\%) of the 72 horses, $16(18.2 \%)$ of the 88 donkeys and $8(25 \%)$ of the 32 mules. Irrespective of equine species, seropositive titers were determined at $1 / 16$ dilution in $30(15.6 \%)$ samples, $1 / 64$ dilution in $8(4.2 \%)$, and $1 / 256$ dilution in $6(3.1 \%)$ samples. Seropositivity among males and females was 14 (19.4\%) and 30 (25\%), respectively. There was no significant difference between the sex groups $(P>0.05)$. Regarding age of animals, the recorded prevalence was $14.3 \%$ in $0-5$ age group, $32.8 \%$ in $6-10$ age group and $20.8 \%$ in age group over 11 years. Statistically significant difference was observed among age groups $(P>0.05)$ (Table 1$)$.

Table 1. The serological results of the equines tested for T. gondii seropositivity.

\begin{tabular}{|c|c|c|c|c|c|}
\hline \multirow{2}{*}{ Variable } & & \multirow{2}{*}{ Sample size (No.) } & \multicolumn{2}{|c|}{ Seropositive equines } & \multirow{2}{*}{ Statistical analysis ( $P$ values) } \\
\hline & & & No. & $\%$ & \\
\hline \multirow[t]{3}{*}{ Species } & Horses & 72 & 20 & 27.8 & \multirow{3}{*}{$0.340(\mathrm{NS})$} \\
\hline & Donkeys & 88 & 16 & 18.2 & \\
\hline & Mules & 32 & 8 & 25.0 & \\
\hline \multirow[t]{2}{*}{ Gender } & Male & 72 & 14 & 19.4 & \multirow{2}{*}{$0.240(\mathrm{NS})$} \\
\hline & Female & 120 & 30 & 25.0 & \\
\hline \multirow[t]{3}{*}{ Age (years) } & $0-5$ & 56 & 8 & 14.3 & \multirow{3}{*}{$0.048(S)^{*}$} \\
\hline & $6-10$ & 64 & 21 & 32.8 & \\
\hline & $\geq 11$ & 72 & 15 & 20.8 & \\
\hline
\end{tabular}

No.: Number; NS: Not significant; S: Significant.

\section{DISCUSSION}

Several studies aiming for the detection of prevalence of $T$. gondii in different animal species by various serologic tests including latex agglutination test ${ }^{[11]}$, indirect hemagglutination test ${ }^{[12]}$, modified agglutination test $\mathrm{t}^{[12]}$, indirect fluorescent antibody test $^{[13]}$ and SFDT ${ }^{[14]}$ have been reported from different countries throughout the World.

The prevalence of $T$. gondii infection in horses was reported to range from $0 \%$ to $80 \%$ in different countries $^{[15,16,17]}$. The prevalence of seropositive samples for $T$. gondii in horses found in the present study $(27.8 \%)$ was higher than that reported from
Spain $(10.8 \%)^{[18]}$, Mexico $(6.1 \%)^{[19]}$, United States of America $(6.9 \%)^{[20]}$, South Korea $(2.6 \%)^{[21]}$, and Sweden $(1 \%)^{[22]}$. However, the prevalence observed in our study was lower than that reported in Saudi Arabia $(31.6 \%)^{[23]}$, Southwestern China $(30.5 \%)^{[24]}$ and Sudan $(30.04 \%)^{[25]}$.

Seropositivity for T. gondii infection in donkeys was reported as 30\% in Northwestern Algeria ${ }^{[24]}, 58.7 \%$ in Pakistan $^{[26]}, 47 \%$ in $\operatorname{Iran}^{[27]}, 65.6 \%$ in Egypt ${ }^{[28]}$ and 5\%$8 \%$ in Italy ${ }^{[29]}$. While the seroprevalence in mules was found to be $23.8 \%$ in Brazil ${ }^{[30]}$ and 15\% in Spain ${ }^{[18]}$.

Numerous studies were also carried out to record the seroprevalence of $T$. gondii in equines in Turkey. 
The studies and the determined rates are given in table (2).

The recorded data showed that the highest rate was found in Erzurum province with $62 \%{ }^{[39]}$ and the lowest rate was in Van province with $1.7 \%^{[33]}$. Seroprevalence observed in the present study for horses (27.8\%) was higher than those reported from Malatya, Van, Kayseri, Kars, Şanlıurfa and Niğde provinces while it was similar to those reported from Ankara and Hakkari provinces (Table 2). On the other hand, seroprevalence found in the present study for donkeys was lower than those reported from Kayseri and Erzurum provinces. The seroprevalence in females and males were 25\% and $19.4 \%$, respectively. No statistically significant difference was found between T. gondii infections and gender $(P=0.240)$. Similar findings were also reported by other studies ${ }^{[18,40,41]}$.

The seroprevalence of $T$. gondii infection showed a statistically significant difference among age groups and the maximum seroprevalence was observed in the age-group of 6-10 years. This finding was in concordance with Rouatbi et $a l_{.}^{[42]}$, Güclü et $a l^{[37]}$ and Machacova et al. ${ }^{[29]}$. The results indicated an increase in the risk of toxoplasmosis in correspondence with the increase in age $\mathrm{e}^{[29,37,42]}$.

In this study, it was concluded that seroprevalence of $T$. gondii was determined as $22.9 \%$ in equines in Isparta province, Turkey. The T. gondii infection was found in $27.8 \%$ of horses, $18.2 \%$ of donkeys and $25 \%$ of mules.

Table 2. Seroprevalence of $T$. gondii antibodies in equines in Turkey.

\begin{tabular}{lcccc}
\hline \hline \multirow{2}{*}{ Cities } & \multicolumn{2}{c}{ Seroprevalence } & Reference \\
\cline { 2 - 5 } & Method & Species & 20.6 & {$[9]$} \\
Kars & SFDT & Horse & 2.0 & {$[31]$} \\
Mnkara & SFDT & Horse & 6.4 & {$[32]$} \\
Van & SFDT & Horse & 1.7 & {$[33]$} \\
Kayseri & IHA & Horse & 10.4 & {$[34]$} \\
Kayseri & SFDT & Horse & 10.0 & {$[34]$} \\
Kayseri & MFDT & Mule & 42.42 & {$[35]$} \\
Şanlıurfa & SFDT & Horse & 13.5 & {$[36]$} \\
Hakkari & SFDT & Horse & 28.3 & {$[36]$} \\
Hakkari & IHA & Horse & 28.0 & {$[37]$} \\
Ankara & SFDT & Horse & 7.0 & {$[38]$} \\
Niğde & SFDT & Horse & 62 & {$[39]$} \\
Erzurum & SFDT & Donkey & \\
\hline \hline
\end{tabular}

SFDT: Sabin Feldman dye test, IHA: Indirect hemagglutination test

Authors contribution: Aciöz $M$ conceived and supervised the study. Acıöz M, Babür C and Bozkaya F collected and analyzed data. Acıöz M wrote the first draft of manuscript. All authors contributed to the critical revision of the manuscript and have read and approved the final version.

Conflicts of interest: We declared that there is no conflict of interest.

Funding statement: The research received no funding.

\section{REFERENCES}

1. Achaw B, Tesfa H, Zeleke AJ, Worku L, Addisu A, Yigzaw $\mathrm{N}$, et al. Sero-prevalence of Toxoplasma gondii and associated risk factors among psychiatric outpatients attending University of Gondar Hospital, Northwest Ethiopia. BMC Infect Dis 2019; 9(1):581-588.

2. Akca A, Babur C, Arslan MO, Gicik Y, Kara M, Kılıc S. Prevalence of antibodies to Toxoplasma gondii in horses in the province of Kars, Turkey. Vet Med 2004; 49(1):9-13.
3. Akkan HA, Tutuncu M, Karaca M, Ciftc IH, Yuksel N, Agaoglu Z. Seroprevalence of Toxoplasma gondii in horses in Van Province. YYU Vet Fak Derg 2001; 12(12):43-44.

4. Aktas M, Babur C, Koroglu E, Duman N. Detection of anti-Toxoplasma gondii antibodies using SabinFeldman dye test in horses in Sultansuyu Agriculture Unit in Malatya. Firat Univ Sagl Bilim Vet Derg 1999; 13:89-91.

5. Alanazi AD, Alyousif MS. Prevalence of antibodies to Toxoplasma gondii in horses in Riyadh Province, Saudi Arabia. J Parasitol 2011; 97(5): 943-945.

6. Alvarado-Esquivel C, Rodríguez-Peña S, Villena I, Dubey JP. Seroprevalence of Toxoplasma gondii infection in domestic horses in Durango State, Mexico. J Parasitol 2012; 98 (5):944-945.

7. Ashburn D, Chatterton JM, Evans R, Joss AW, Ho-Yen DO. Success in the Toxoplasma dye test. J Infection 2001; 42(1):16-19.

8. Atasever A, Ekebaş G, Yaman Gram D, Babür C, Inci, A. Experimentalt toxoplasmosis in pigeons (Columba livia). AJRID 2020; 3(1):16-26. 
9. Babur C, Cakmak A, Biyikoglu G, Piskin FC. The detection of anti-Toxoplasma gondii antibodies by Sabin Feldman dye test in horses which were slaughtered to feed the wild animals in the zoo of the Ankara Ataturk Forest Farm. Turkiye Parazitol Derg 1998; 22:174-176.

10. Balkaya I, Babur C, Celebi B, Utuk AE. Seroprevalence of toxoplasmosis in donkeys in Eastern Turkey. Israel J Vet Med 2011; 66(2):39-42.

11. Belluco S, Simonato G, Mancin M, Pietrobelli M, Ricci A. Toxoplasma gondii infection and food consumption: A systematic review and meta-analysis of case-controlled studies. Crit Rev Food Sci Nutr 2018; 58(18):30853096.

12. de Oliveira E, de Albuquerque PP, de Souza Neto OL, Faria EB, Júnior JW, Mota RA. Occurrence of antibodies to Toxoplasma gondii in mules and donkeys in the northeast of Brazil. J Parasitol 2012; 99(2):343-345.

13. Degroote RL, Deeg CA. Immunological insights in equine recurrent uveitis. Front Immunol, 08 Jan 2021. DOI: 10.3389/fimmu.2020.609855.

14. Dubey JP, Thulliez P, Romand S, Kwok OC, Shen SK, Gamble HR. Serological prevalence of Toxoplasma gondii in horses slaughtered for food in North America. Vet Parasitol 1999; 86:235-238.

15. Ducrocq J, Simon A, Lemire M, De Serres G, Lévesque B. Exposure to Toxoplasma gondii through consumption of raw or undercooked meat: A systematic review and meta-analysis. Vector Borne Zoonotic Dis 2020; 21(1):1-10.

16. El-Ghaysh A. Seroprevalence of Toxoplasma gondii in Egyptian donkeys using ELISA. Vet Parasitol 1998; 80(1):71-73.

17. Fericstah D, Çabuk UC, Arikan E, Gürkan A. An Analysis of the positioning accuracy of iBeacon technology in indoor environments. In Proceedings of the 2017 International Conference on Computer Science and Engineering (UBMK), Antalya, Turkey, 5-8 October 2017; pp. 549-553.

18. Fernandes $\mathrm{S}$, Brilhante-Simões $\mathrm{P}$, Coutinho $\mathrm{T}$, Cardoso L, Dubey JP, Lopes AP. Comparison of indirect and modified agglutination tests for detection of antibodies to Toxoplasma gondii in domestic cats. JVDI 2019; 31(5):774-777.

19. García-Bocanegra Y, Cabezón O, Arenas-Montes A, Carbonero A, Dubey JP, Perea A, et al. Seroprevalence of Toxoplasma gondii in equids from southern Spain. Parasitol Int 2012; 61(3):421-424.

20. Gharekhani J, Gerami-Sadeghian A, Tavoosidana G, Sohrabei A: Seroepidemiology of Toxoplasma gondii infection in dogs and domestic equine from Western Iran. Comp Clin Pathol 2015; 24:255-258.

21. Goz Y, Babur C, Aydin A, Kilic S. Seroprevalence of toxoplasmosis, brucellosis and listeriosis in horses in Hakkari eastern region of Turkey. Prev Vet Med 2007; 158(11):534-539.

22. Guclu Z, Karaer Z, Babur C, Kilic S. Investigation of Toxoplasma gondii antibodies in sport horses bred in Ankara Province. Turkiye Parazitol Derg 2007; 31(4):264-267.
23. Gupta GD, Lakritz J, Kim JH, Kim DY, Kim JK, Marsh AE. Seroprevalence of Neospora, Toxoplasma gondii and Sarcocystis neurona antibodies in horses from Jeju island, South Korea. Vet Parasitol 2002; 106(3):193201.

24. Haridy FM, Saleh NM, Khalil HH, Morsy TA. AntiToxoplasma gondii antibodies in working donkeys and donkey's milk in greater Cairo, Egypt. J Egypt Soc Parasitol 2010; 40(2): 459-464.

25. Ibrahim AM, Osman OM, Ali RHM, Ismail AA, Angara TEE. Sero-prevalence of Toxoplasma gondii in different horses groups from Khartoum State, Sudan. J Appl Indust Sci 2014; 2(4):152-157.

26. Inci A, Babur C, Aydin N, Cam Y. An investigation into the seroprevalence of Toxoplasma gondii (Nicolle and Manceaux, 1908) and Listeria monocytogenes in equids around Kayseri. Firat Univ Sagl Bilim Vet Derg 2002; 16(2): 181-185.

27. Jakubek EB, Lunde NA, Uggla A. Seroprevalence of Toxoplasma gondii and Neospora sp. infections in Swedish horses. Vet Parasitol 2006; 138(3-4):194199.

28. Karatepe B, Babur C, Karatepe M, Kilic S. Seroprevalence of toxoplasmosis in horses in Nigde Province of Turkey. Trop Anim Hlth Prod 2010; 42(3):385-389.

29. Khan AH, Noordin R. Serological and molecular rapid diagnostic tests for Toxoplasma infection in humans and animals. Eur J Clin Microbiol Infect Dis 2020; 39 (1):19-30.

30. Kolören Z, JP Dubey. A review of toxoplasmosis in humans and animals in Turkey. Parasitology 2019; 47 (1):12-18

31. Machacova T, Bartova E, Di Loria A, Sedlak K, Mariani U, Fusco G, et al. Seroprevalence of Toxoplasma gondii in donkeys (Equus asinus) in Italy. J Vet Med Sci 2013; 76(2):265-267.

32. Mazumder P, Chuang HY, Wentz MW, Wiedbrauk DL. Latex agglutination test for detection of antibodies to Toxoplasma gondii. J Clin Microbiol 1988; 26 (11): 2444-2446.

33. McMullen RJJr, Fischer BM. Medical and surgical management of equine recurrent uveitis. Vet Clin North Am Equine Pract 2017; 33(3):465-481.

34. Meng QF, Li D, Yao GZ, Zou Y, Cong W, Shan XF. Seroprevalence of Toxoplasma gondii infection and variables associated with seropositivity in donkeys in eastern China. Parasite 2018; 25:66-69.

35. Miao Q, Wang X, She L, Fan Y, Yuan F, Yang J, et al. Seroprevalence of Toxoplasma gondii in horses and donkeys in Yunnan Province, Southwestern China. Parasites \& Vectors 2013; 6 (1):168-172.

36. Razmi GR, Abedi V, Yaghfoori S. Serological study of Toxoplasma gondii infection in Turkoman horses in the North Khorasan Province, Iran. J Parasit Dis 2016; 40(2):515-519.

37. Reiter-Owona I, Petersen E, Joynson D, Aspöck H, Dardé ML, Disko R, et al. The past and present role of the Sabin-Feldman dye test in the serodiagnosis of toxoplasmosis. Bull World Health Organ 1999; 77 (11):929-35. 
38. Rouatbi M, Amairia S, Amdouni Y, Boussaadoun MA, Ayadi O, Al-Hosary AAT, et al. Toxoplasma gondii infection and toxoplasmosis in North Africa: a review. Parasite 2019; 26:6-25.

39. Saqib M, Hussain MH, Sajid MS, Mansoor, MK, Asi $\mathrm{MN}$, Fadya A, et al. Sero-epidemiology of equine toxoplasmosis using a latex agglutination test in the three metropolises of Punjab Pakistan. Trop Biomed 2015; 32 (2):276-285.

40. Sevgili M, Babur C, Gökcen A, Nalbantoglu S. Seroprevalence of Toxoplasma gondii (Nicolle and Manceaux, 1908) antibodies in thoroughbred arabian mares as detected by Sabin Feldman dye test in Sanliurfa. Firat Univ Sagl Bilim Vet Derg 2004; 18(1):21-23.

41. Stelzer S, Basso W, Benavides Silván J, Ortega-Mora LM, Maksimov P, Gethmann J, et al. Toxoplasma gondii infection and toxoplasmosis in farm animals: Risk factors and economic impact. Food Waterborne Parasitol 2019; 3; 15: e00037.

42. Zeybek H, Dündar B, Altintas, K, Güngör C. The seroprevalence of toxoplasmosis in equids. Turkiye Parazitol Derg 1998; 22:424-427. 